\title{
Metoprolol: New and Efficient Corrosion Inhibitor for Mild Steel in Hydrochloric and Sulfuric Acid Solutions
}

\author{
Fatemeh Mohammadinejad, ${ }^{1}$ Seyyed Mohammad Ali Hosseini, ${ }^{2,}{ }^{*}$ \\ Mehdi Shahidi Zandi, ${ }^{3}$ Mohammad Javad Bahrami ${ }^{4}$ and Zahra Golshani ${ }^{5}$ \\ ${ }^{1}$ Department of Chemistry, Shahid Bahonar University of Kerman, P.O. Box: 76169-14111, Kerman, Iran. \\ 2 Department of Chemistry, Shahid Bahonar University of Kerman, P.O. Box: 76169 14111, Kerman, Iran. \\ ${ }^{3}$ Department of Chemistry, Kerman Branch, Islamic Azad University, P.O. Box: 7635131167, Kerman, Iran. \\ ${ }^{4}$ Department of Science, Farhangian University, P.O. Box: 76175173, Kerman, Iran. \\ ${ }^{5}$ Department of Chemistry, Shahid Bahonar University of Kerman, P.O. Box: 76169 14111, Kerman, Iran. \\ *Corresponding author: E-mail: s.m.a.hosseini@uk.ac.ir
}

Tel: 0913-3412012

Received: 06-08-2019

\begin{abstract}
The inhibition behavior of metoprolol tablet on steel alloy (st37) in $1 \mathrm{M}$ hydrochloric acid and $0.5 \mathrm{M}$ sulfuric acid solutions were studied by three methods (potentiodynamic polarization, electrochemical impedance spectroscopy, and scanning electronic microscopy, SEM). The obtained parameters revealed that different amounts of metoprolol drug inhibited the corrosion of mild steel in the acid solutions of $\mathrm{HCl}$ and $\mathrm{H}_{2} \mathrm{SO}_{4}$. The corrosion resistance of the alloy increased with the increase in the concentration of metoprolol up to $300 \mathrm{ppm}$ but was reduced by increasing the temperature. The derived parameters from polarization curves indicated that the drug is a mixed type inhibitor. The results obtained from the different methods are consistent with each other. The adsorption of metoprolol was found to be physical, exothermic, and spontaneous, and also fitted the Langmuir adsorption model. SEM micrographs are in accordance with the adsorption performance of the tablet.
\end{abstract}

Keywords: Corrosion Inhibitor; potentiodynamic Polarization; electrochemical Impedance Spectroscopy; mild steel; metoprolol.

\section{Introduction}

Corrosion is the dissolution of metals and alloys exposed to aggressive media and is very difficult to eliminate completely. Inhibition of the corroding material would be more achievable than complete elimination. Demolition of metal and alloys development could be rapid after destruction of the protective film which depends on the composition and character of metals and aggressive media. For example, formation of oxides and diffusion of metal cations into the coating matrix, local $\mathrm{pH}$ changes, and electrochemical potential. ${ }^{1}$ Mild steel is an abundant and efficient building material. However, it is difficult to protect this alloy exposed to harsh environments against corrosion. ${ }^{2}$ Acidic solutions are extensively utilized in different industries for various purposes, including acid pickling, acid descaling, and oil well acidizing. ${ }^{3}$ Due to the general aggressiveness of acid media, the use of effective inhibitors is one of the reliable and economical ways for minimizing the corrosion rates and the protection of metal surfaces against corrosive media. ${ }^{4-6}$ Thus, reliable inhibitors for the corroding materials in reducing acids (hydrochloric acid and sulfuric acid) have attracted the wide attention of researchers. ${ }^{5}$ Organic compounds with $\pi$-bonds and heteroatoms (P, S, N, and $\mathrm{O}$ ) are highly effective and available inhibitors, but most of them are expensive and toxic with 
negative effect on the environment. ${ }^{7-12}$ These properties restrict their use to reduce the corrosion of metals and alloys. Therefore, it is very important and necessary to find out the least expensive and environmentally safe corrosion inhibitors. ${ }^{13,14}$ Earlier report ${ }^{15}$ indicates that the use of drugs for the protection of metals corrosion offers some advantages in comparison to the use of some organic/inorganic inhibitors due to their eco-environmental nature. Most of the drugs are nontoxic and less expensive with limited negative effects on different media, so they are suggested to replace the traditional toxic corrosion inhibitors. ${ }^{16}$ Thus, in the present investigation the effect of metoprolol tablet on the corrosion resistance of mild steel in 1.0 $\mathrm{M}$ hydrochloric acid and $0.5 \mathrm{M}$ sulfuric acid solutions was done. The selection of this drug as corrosion inhibitor is done on the ground of its low toxicity and high solubility in acidic media. Electrochemical impedance spectroscopy (EIS), potentiodynamic polarization, and scanning electronic microscopy (SEM) methods were employed to evaluate corrosion rate of the steel and inhibition efficiency of the drug.

\section{Experimental}

\section{1. Materials and Solutions}

Metoprolol tablets are commercially obtained as a trade name Lopressor, Toprol-xl by Toliddaru Company. The compound in its purest state has the molecular formula of $\mathrm{C}_{15} \mathrm{H}_{25} \mathrm{NO}_{3}$ and melting point $120^{\circ} \mathrm{C}$. No attempt was made to eliminate the effect of excipients from the tablets. The molecular structure of metoprolol used in this study is given in Fig. 1. At first, solutions of 2.0 M hydrochloric and 1.0 M sulfuric acid were prepared for each experiment in distilled water using analytical grade $37 \% \mathrm{HCl}$ and $98 \%$ $\mathrm{H}_{2} \mathrm{SO}_{4}$ purchased from Sigma-Aldrich. Various amounts of the tablet $(1000,800,600,400$, and $100 \mathrm{ppm})$ were added to the acids solutions, with adequate volume of acid and inhibitor (the tablet was dissolved in distilled water and passed through the filter paper without purification) to get the desired concentration of acids $(1.0 \mathrm{M} \mathrm{HCl}$ and $0.5 \mathrm{M}$ $\mathrm{H}_{2} \mathrm{SO}_{4}$ ) and 500-50 ppm of inhibitor. Mild steel samples of the following composition were used (in wt. \%): C 0.17; Si 0.5; Mn 1.4; S 0.045; Fe to balance. The specimens were mechanically cut into $1 \mathrm{~cm}^{2}$ pieces. Prior to all measurements, the samples were polished using different grades of emery papers (600-3000), degreased with acetone and finally washed with distilled water and dried in air, then im-

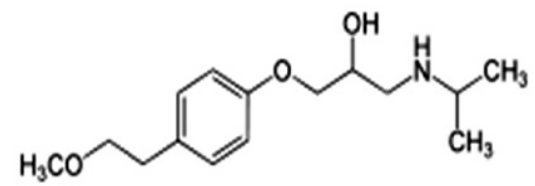

Figure 1. Molecular structure of metoprolol (RS)-1-(isopropylamino)-3-[4-(2-methoxyethyl)-phenoxy]-propan-2-ol. mersed in the solutions for $30 \mathrm{~min}$ (to get stable OCP) before each EIS test.

\section{2. Procedures}

\section{2. 1. Electrochemical Measurements: Potentiodynamic Polarization and Electrochemical Impedance Spectroscopy (EIS)}

The electrochemical measurements were carried out with an Autolab potentiostat/galvanostat (AUTOLAB-302N, Netherlands) by using a three-electrode cell containing Ag/ $\mathrm{AgCl}$ as reference (with $0.197 \mathrm{mV}$ ), Pt electrode as counter and mild steel as working electrode used for this investigation. The potential range for potentiodynamic polarization tests was -850 to $-200 \mathrm{mV}$ and the scan rate was $1 \mathrm{mV} / \mathrm{s}$. The frequency range for EIS tests was $100 \mathrm{mHz}$ to $100 \mathrm{kHz}$ and the EIS amplitude was $10 \mathrm{mV}$ peak to peak. Before each polarization and impedance test, potential was stabilized within $30 \mathrm{~min}$ at $25 \pm 1{ }^{\circ} \mathrm{C}$. Finally, all of the curves were analyzed with Nova software (Utrecht, The Netherlands).

\section{2. 2. Effect of Temperature}

The effect of temperature on the corrosion rate of mild steel in both acids solutions with and without various concentrations of inhibitor in the temperature range of $25-55 \pm 1{ }^{\circ} \mathrm{C}$ was investigated by potentiodynamic polarization technique.

\section{2. 3. Scanning Electron Microscopic (SEM) Studies}

The surface morphology of the working electrode was examined after immersion of the alloy for about $24 \mathrm{~h}$ in $1 \mathrm{M} \mathrm{HCl}$ and $0.5 \mathrm{M} \mathrm{H}_{2} \mathrm{SO}_{4}$ solutions at room temperature, in the absence and presence of the optimum concentration of metoprolol using scanning electron microscopy (SEM). Scans were taken with a EM3200 instrument (accelerating voltage $0-30 \mathrm{kV}$ ) from KYKY company, China.

\section{Results and Discussion}

\section{1. Electrochemical Impedance Spectroscopy}

Electrochemical impedance spectroscopy (EIS) has been employed in order to investigate the surface layer formed by the inhibitor. The effect of metoprolol concentrations on the impedance behavior of mild steel in $1.0 \mathrm{M}$ hydrochloric acid and $0.5 \mathrm{M}$ sulfuric acid solutions at $25 \pm$ $1{ }^{\circ} \mathrm{C}$ is shown in Fig. 2. Inhibitor efficiency can also be estimated by charge transfer resistance according to the following equation: ${ }^{17}$

$$
\mathrm{IE} \%=\left(\frac{R_{c t}^{i}-\mathrm{R}_{c t}^{o}}{R_{c t}^{i}}\right) \times 100
$$


where $R_{c t}^{i}$ and $R_{c t}^{0}$ are charge transfer resistances of mild steel in the absence and presence of inhibitor, respectively. Inhibition efficiency increased with the concentration of inhibitor up to $300 \mathrm{ppm}$ and further increase in the inhibitor concentration did not cause any appreciable change in the inhibition performance.

Fig. 3 illustrates the electrical equivalent circuit employed to analyze the impedance plots. In this Figure, $R_{s}$ is the solution resistance and $\mathrm{R}_{\mathrm{ct}}$ is the charge transfer resistance. The impedance of the constant phase element (CPE) is defined as bellow: ${ }^{18}$

$$
\mathrm{Z}_{\mathrm{CPE}}=\mathrm{A}^{-1}(\mathrm{i} \omega)^{-\mathrm{n}}
$$

where A is proportionality coefficient, $\omega$ is angular frequency (in rad./s) and $\mathrm{i}=-1$ is the imaginary number. The correct equation to convert the $\mathrm{CPE}$ constant, $\mathrm{A}$, into the double layer capacitance, $\mathrm{C}_{\mathrm{dl}}$, is: ${ }^{19}$

$$
\mathrm{C}_{\mathrm{dl}}=\frac{1}{2 \pi \omega_{\max } \mathrm{R}_{c \mathrm{t}}}
$$

where is the frequency at which the imaginary component of the impedance is maximum. The electrochemical pa-

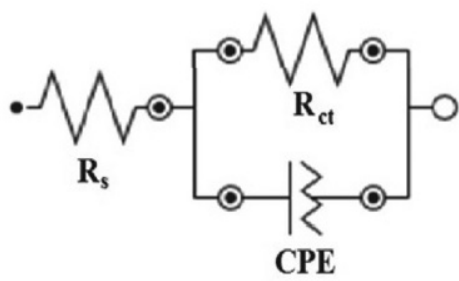

Figure 3. Equivalent circuit to estimate impedance diagrams.

a)

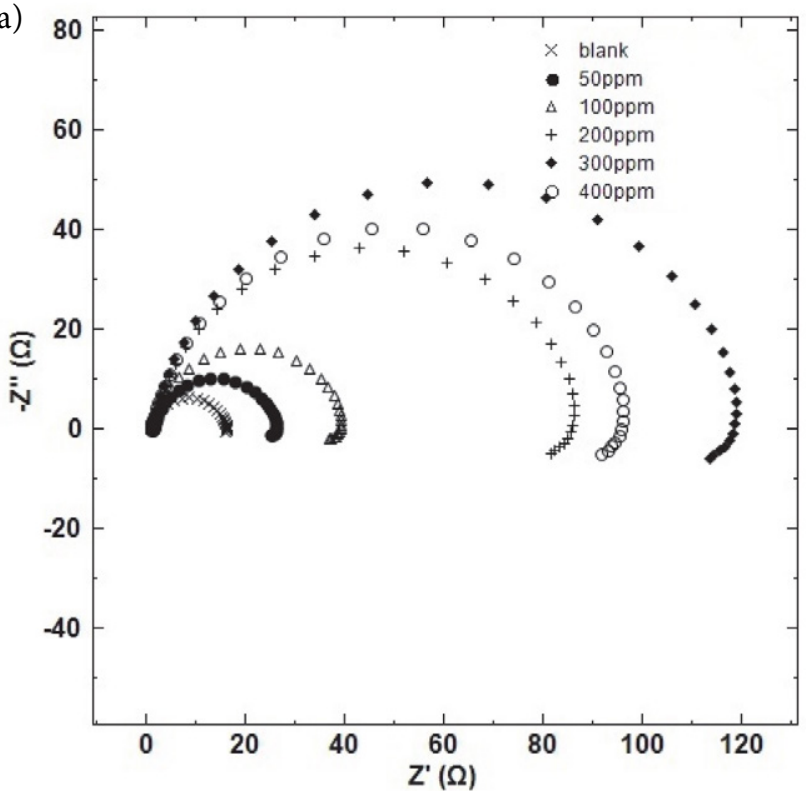

rameters, obtained from fitting of the recorded EIS data are listed in Table 1. In this table, the calculated double-layer capacitance $\left(\mathrm{C}_{\mathrm{dl}}\right)$ values derived from the CPE parameters are also given and standard deviation (S.D.) and mean $(\bar{X})$ values are calculated.

Table 1. Corrosion parameters derived from Nyquist curves for mild steel in a) hydrochloric acid and b) sulfuric acid solution in absence and presence of different concentrations of inhibitor at $25 \pm$ $1{ }^{\circ} \mathrm{C}$. (Results derived from at least two repeats of experiment.)

a)

\begin{tabular}{ccccr}
\hline $\begin{array}{c}\text { inhibitor } \\
\text { concentration } \\
(\mathbf{p p m})\end{array}$ & $\mathrm{C}_{\mathbf{d l}} / \boldsymbol{\mu F} / \mathbf{c m}^{2}$ & $\mathbf{R}_{\mathrm{ct}} / \mathbf{\Omega} \mathbf{c m}^{2} \pm$ S.D. & IE\% & $\overline{\boldsymbol{X}}$ \\
\hline Blank & 368 & $15.0 \pm 0.00$ & - & 15.0 \\
50 & 299 & $25.0 \pm 1.53$ & 40 & 25.3 \\
100 & 196 & $38.0 \pm 2.08$ & 60 & 36.7 \\
200 & 116 & $86.0 \pm 2.00$ & 82 & 88.0 \\
300 & 62 & $121.0 \pm 1.53$ & 87 & 122.3 \\
400 & 103 & $97.0 \pm 2.08$ & 84 & 98.7 \\
\hline
\end{tabular}

b)

\begin{tabular}{ccccc}
\hline $\begin{array}{c}\text { inhibitor } \\
\text { concentration } \\
(\mathbf{p p m})\end{array}$ & $\mathrm{C}_{\mathbf{d l}} / \boldsymbol{\mu F} / \mathbf{c m}^{2}$ & $\mathbf{R}_{\mathrm{ct}} / \mathbf{\Omega} \mathbf{c m}^{2} \pm \mathbf{S} . \mathrm{D}$. & $\mathrm{IE} \%$ & $\overline{\boldsymbol{X}}$ \\
\hline Blank & 607 & $16.0 \pm 0.00$ & - & 16.0 \\
50 & 506 & $26.0 \pm 1.53$ & 37 & 26.3 \\
100 & 318 & $31.0 \pm 1.53$ & 50 & 32.3 \\
200 & 190 & $40.0 \pm 1.53$ & 58 & 41.3 \\
300 & 136 & $55.0 \pm 1.53$ & 70 & 56.3 \\
400 & 241 & $41.0 \pm 1.53$ & 60 & 40.6 \\
\hline
\end{tabular}

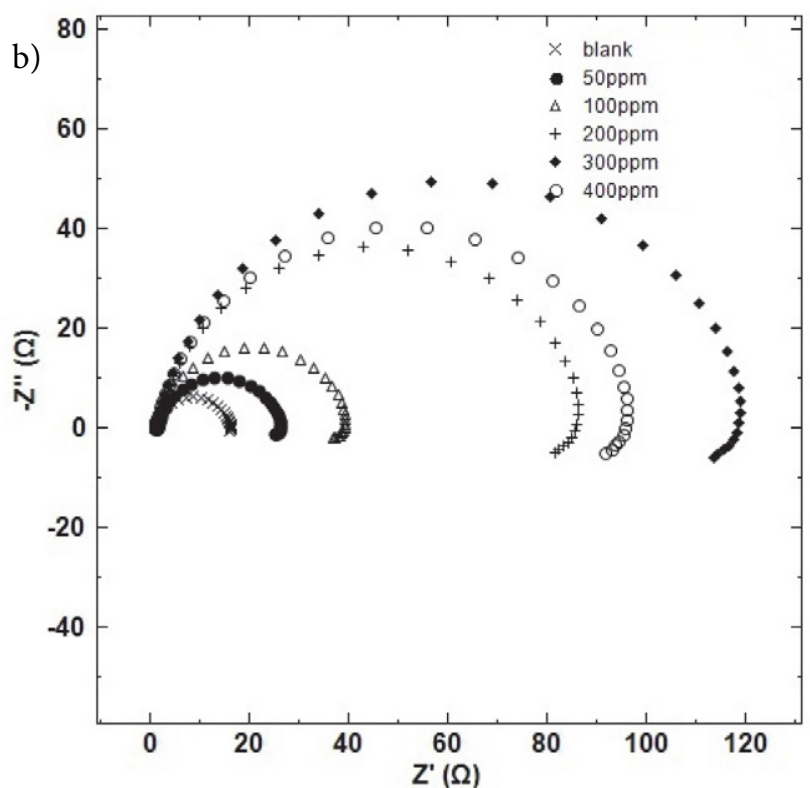

Figure 2. Nyquist curves for mild steel in a) $1 \mathrm{M}$ hydrochloric acid solution and b) $0.5 \mathrm{M}$ sulfuric acid solution in absence and presence of different concentrations of inhibitor at $25 \pm 1{ }^{\circ} \mathrm{C}$. (The experiments were repeated at least two times) 


\section{2. Potentiodynamic Polarization}

Fig. 4 presents the potentiodynamic polarization curves of mild steel in $1 \mathrm{M} \mathrm{HCl}$ and $0.5 \mathrm{M} \mathrm{H}_{2} \mathrm{SO}_{4}$ in the blank and solution containing various concentrations of tablet. The relevant parameters are gathered in Table 2, i.e. corrosion current density $\left(\mathrm{i}_{\text {corr }}\right)$, corrosion potential $\left(\mathrm{E}_{\text {corr }}\right)$, surface coverage $(\theta)$, anodic and cathodic Tafel slopes $(\beta \mathrm{a}, \beta \mathrm{c})$. The corrosion current density decreased as the concentration of inhibitor increased up to $300 \mathrm{ppm}$, then decreased. Addition of inhibitor to acid media affected both cathodic and anodic branches of the polarization curves. But the corrosion potential did not change noticably. Therefore, metoprolol behaved as mixed-type inhibitor. In addition to the above parameters, Table 2 depicts the values of corrosion inhibition efficiencies (IE) that were calculated using the appropriate equation: ${ }^{20}$

$$
\mathrm{IE} \%=\left(\frac{\mathrm{l}_{\text {corr }}-\mathrm{l}_{\text {inh }}}{\mathrm{j}_{\text {corr }}}\right) \times 100
$$

where $i_{\text {corr }}$ and $i_{\text {inh }}$ are the corrosion current densities in the experiments without and with inhibition, respectively.
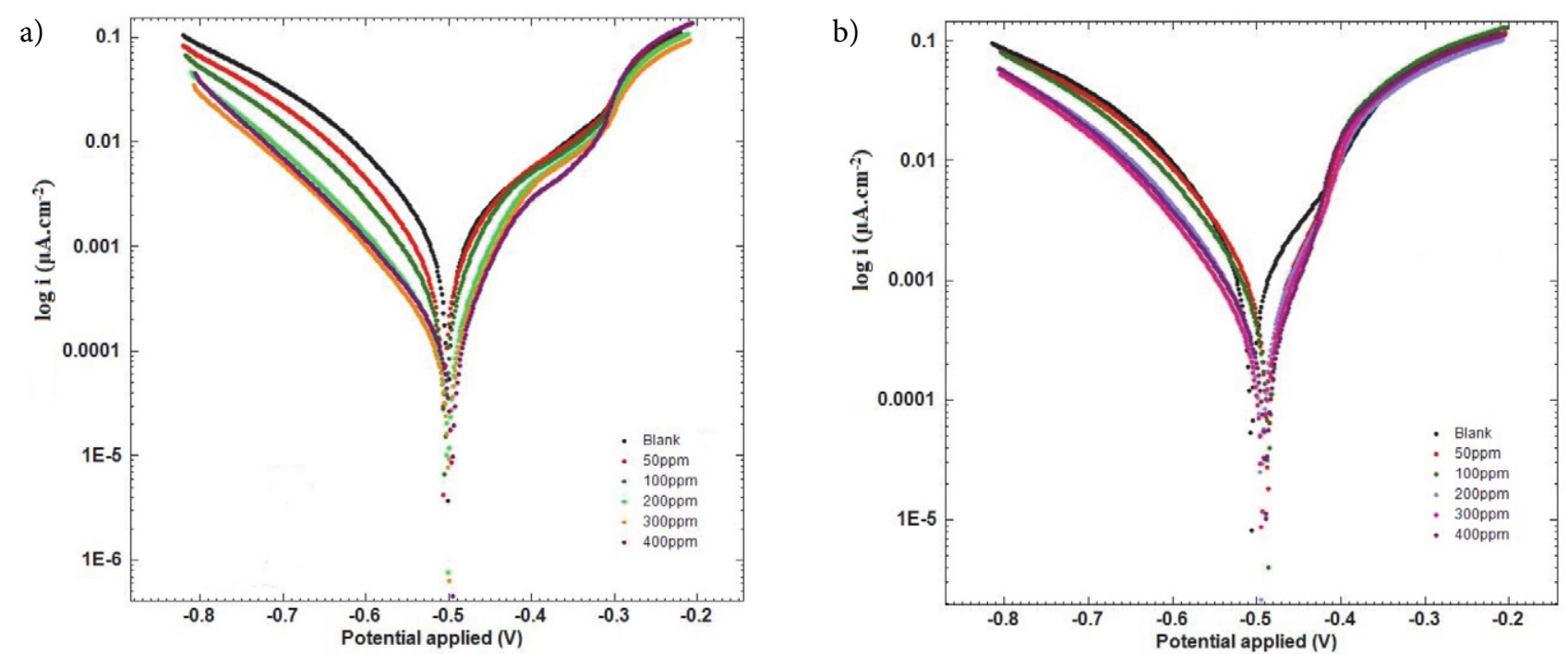

Figure 4. Polarization curves for mild steel in a) $1 \mathrm{M}$ hydrochloric acid and b) $0.5 \mathrm{M}$ sulfuric acid solution in absence and presence of different concentrations of inhibitor at $25 \pm 1{ }^{\circ} \mathrm{C}$. (The experiments were repeated at least two times)

Table 2. Corrosion parameters derived from polarization curves for mild steel in a) hydrochloric acid and b) sulfuric acid solution in absence and presence of different concentrations of inhibitor at $25 \pm 1{ }^{\circ} \mathrm{C}$. (Results derived from at least two repeats of experiment.)

a)

\begin{tabular}{ccccccrr}
\hline $\begin{array}{c}\text { inhibitor } \\
\text { concentration } \\
(\mathbf{p p m})\end{array}$ & $\mathbf{i}_{\text {corr }} / \mathbf{\mu} \mathbf{A} / \mathbf{c m}^{2} \pm \mathbf{S . D}$. & $-\mathbf{E}_{\text {corr }} / \mathbf{m V}$ & $\boldsymbol{\beta}_{\mathbf{c}} / \mathbf{m V} / \mathbf{d e c}$ & $\boldsymbol{\beta}_{\mathbf{a}} / \mathbf{m V} / \mathbf{d e c}$ & $\boldsymbol{\theta}$ & IE\% & $\overline{\boldsymbol{X}}$ \\
\hline Blank & $1553.0 \pm 1.41$ & 503 & 176 & 142 & - & - & 1552.0 \\
50 & $568.0 \pm 6.03$ & 508 & 93 & 101 & 0.63 & 63 & 574.0 \\
100 & $415.0 \pm 2.52$ & 506 & 83 & 113 & 0.73 & 73 & 420.0 \\
200 & $161.0 \pm 4.70$ & 498 & 74 & 114 & 0.90 & 90 & 166.0 \\
300 & $99.0 \pm 7.02$ & 502 & 95 & 54 & 0.94 & 94 & 97.0 \\
400 & $135.0 \pm 5.51$ & 498 & 65 & 107 & 0.91 & 91 & 141.0 \\
\hline
\end{tabular}

b)

\begin{tabular}{ccccccrr}
\hline $\begin{array}{c}\text { inhibitor } \\
\text { concentration } \\
(\mathbf{p p m})\end{array}$ & $\mathbf{i}_{\text {corr }} / \boldsymbol{\mu \mathbf { A } / \mathbf { c m } ^ { 2 } \pm \mathbf { S . D } .}$ & $-\mathbf{E}_{\text {corr }} / \mathbf{m V}$ & $\boldsymbol{\beta}_{\mathbf{c}} / \mathbf{m V} / \mathbf{d e c}$ & $\boldsymbol{\beta}_{\mathbf{a}} / \mathbf{m V} / \mathbf{d e c}$ & $\boldsymbol{\theta}$ & $\mathbf{I E} \%$ & $\overline{\boldsymbol{X}}$ \\
\hline blank & $1823.0 \pm 02.12$ & 508 & 141 & 113 & - & - & 1821.5 \\
50 & $739.0 \pm 6.00$ & 488 & 109 & 62 & 0.59 & 59 & 745.0 \\
100 & $657.0 \pm 6.12$ & 487 & 118 & 57 & 0.64 & 64 & 662.0 \\
200 & $569.0 \pm 6.11$ & 496 & 123 & 71 & 0.68 & 68 & 559.7 \\
300 & $308.0 \pm 6.36$ & 495 & 67 & 102 & 0.83 & 83 & 312.5 \\
400 & $480.0 \pm 6.50$ & 491 & 122 & 59 & 0.74 & 74 & 479.7 \\
\hline
\end{tabular}


The IE values indicate that the inhibition is pronounced with increasing the inhibitor amount. Higher concentrations (above $300 \mathrm{ppm}$ ) did not affect the IE values (experiments at above $400 \mathrm{ppm}$ (i.e. $500 \mathrm{ppm}$ ) of inhibitor were done but the results did not reveal appreciable changes, so due to overlapping of curves, these results are not given). The results show that the drug acts as an effective inhibitor. The calculated efficiencies obtained from polarization technique are in a close correlation with those obtained from charge transfer resistance.

\section{3. Effect of Temperature}

The effect of temperature on the resistance performance of metoprolol on mild steel in $1 \mathrm{M} \mathrm{HCl}$ and $0.5 \mathrm{M}$ $\mathrm{H}_{2} \mathrm{SO}_{4}$ was probed by potentiodynamic polarization measurements at optimum concentration of metoprolol. The
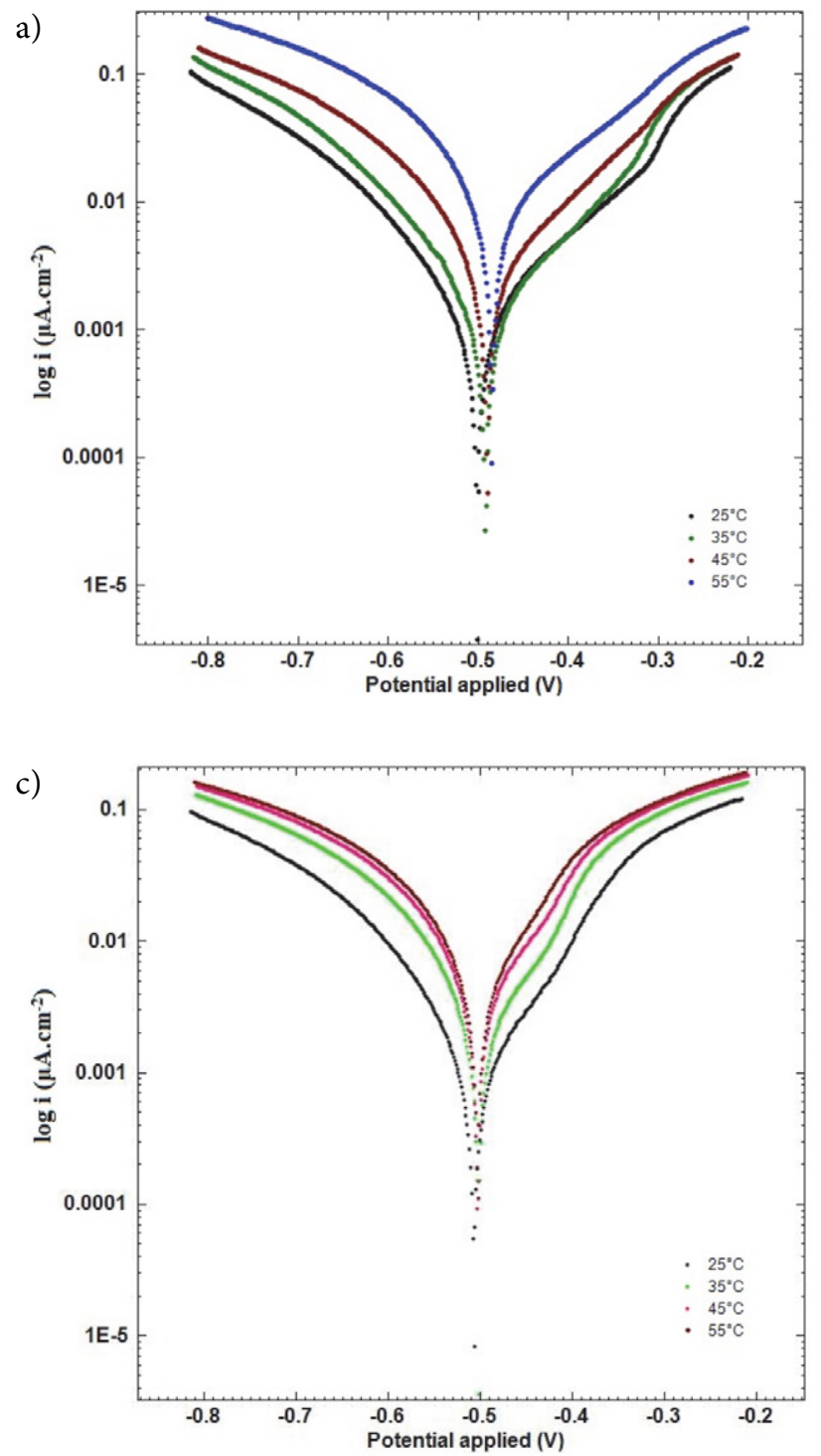

polarization curves in the absence and presence of 300 ppm metoprolol and in temperature range of $25-55 \pm 1{ }^{\circ} \mathrm{C}$ are given in Fig. 5 and the corrosion parameters are listed in Table 3. The results obtained from polarization curves revealed an increase in current density and a decrease in IE values with rising temperature.

Important information on the mechanism of the inhibitor action could be obtained by comparing apparent activation energy $\left(E_{a}\right)$, derived in the presence of inhibitor and its absence. $E_{a}$ values were calculated from Arrhenius equation: ${ }^{21}$

$$
\mathrm{i}_{\text {corr }}=\mathrm{A} \exp \left(\frac{-\mathrm{E}_{\mathrm{a}}}{\mathrm{RT}}\right)
$$

where $\mathrm{i}_{\text {corr }}$ is corrosion current, $\mathrm{A}$ is a constant and $\mathrm{T}$ is the temperature. Fig. 6 shows the Arrhenius plots for the cor-
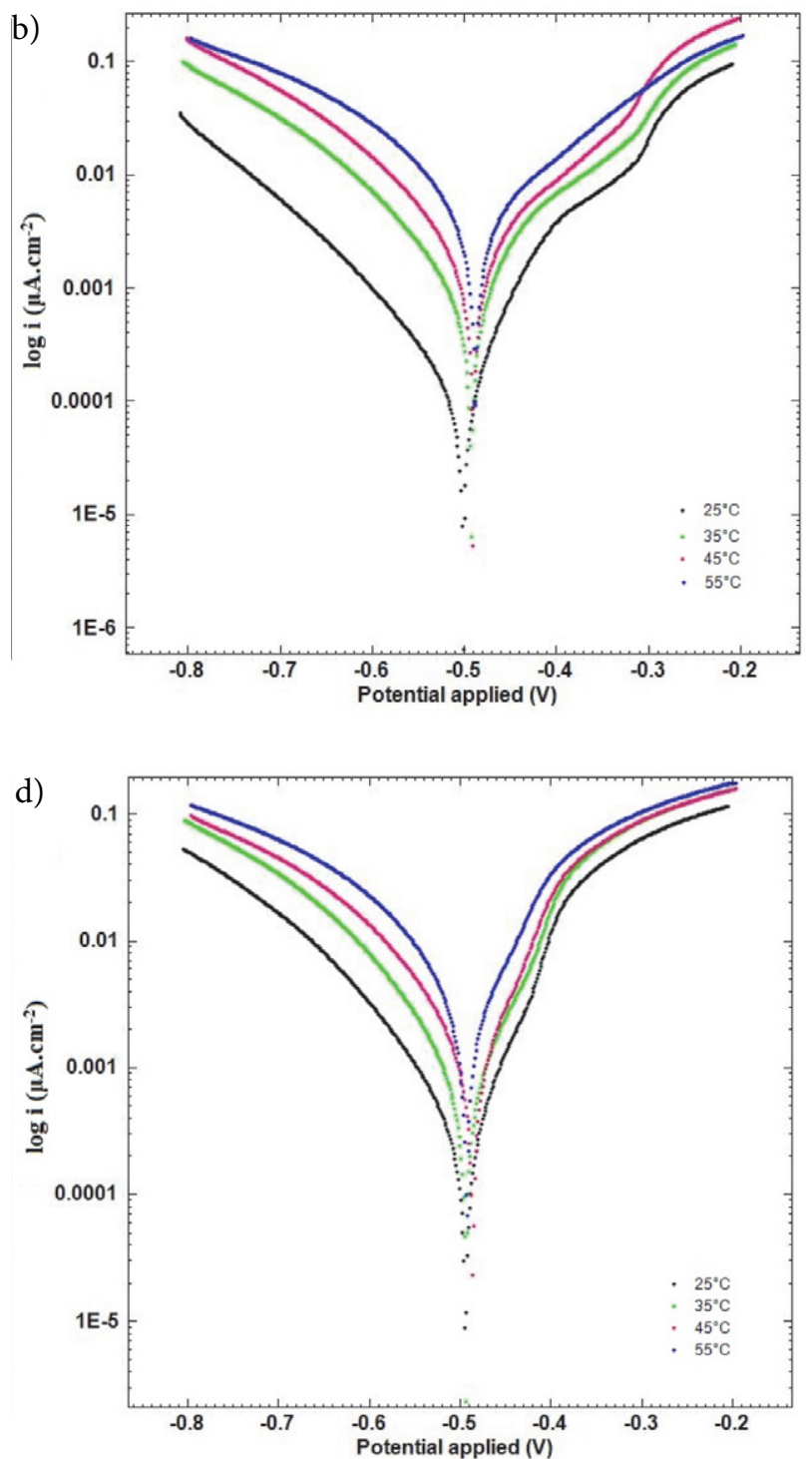

Figure 5. Effect of temperature on the polarization curves in $1 \mathrm{M}$ hydrochloric acid solution a) without inhibitor b) with $300 \mathrm{ppm}$ of inhibitor and $0.5 \mathrm{M}$ sulfuric acid solution c) without inhibitor d) with $300 \mathrm{ppm}$ of inhibitor. (The experiments were repeated at least two times.) 
Table 3. Corrosion parameters calculated from polarization measurements in $1 \mathrm{M}$ hydrochloric acid a) without inhibitor b) with 300 ppm of inhibitor and sulfuric acid solution c) without inhibitor d) with $300 \mathrm{ppm}$ of inhibitor, at different temperatures. (Results derived from at least two repeats of experiment.)

\begin{tabular}{cccr}
\hline \multicolumn{5}{l}{ a) } \\
$\begin{array}{c}\text { temperature } \\
\left(\mathbf{C}^{\circ}\right)\end{array}$ & $\begin{array}{c}\mathbf{i}_{\text {corr }} / \boldsymbol{\mu A} / \mathbf{c m}^{2} \\
\pm \text { S.D. }\end{array}$ & - Ecorr $/ \mathbf{m V}$ & $\overline{\boldsymbol{X}}$ \\
\hline 25 & $1553.0 \pm 1.41$ & 502 & 1552.0 \\
35 & $1867.0 \pm 9.90$ & 494 & 1860.0 \\
45 & $2993.0 \pm 7.80$ & 492 & 2978.5 \\
55 & $6873.00 \pm 9.20$ & 486 & 6866.50
\end{tabular}

b)

\begin{tabular}{|c|c|c|c|c|}
\hline $\begin{array}{c}\text { temperature } \\
\left(\mathrm{C}^{\circ}\right)\end{array}$ & $\begin{array}{c}\mathrm{i}_{\text {corr }} / \mu \mathrm{A} / \mathrm{cm}^{2} \\
\pm \mathrm{S} . \mathrm{D}\end{array}$ & $-\mathrm{E}_{\text {corr }} / \mathrm{mV}$ & IE\% & $\bar{X}$ \\
\hline 25 & $99.0 \pm 7.02$ & 502 & 94 & 97.0 \\
\hline 35 & $830.0 \pm 7.80$ & 493 & 56 & 824.5 \\
\hline 45 & $1728.0 \pm 7.10$ & 491 & 42 & 1723.0 \\
\hline 55 & $4622.0 \pm 7.07$ & 498 & 35 & 4627.0 \\
\hline \multicolumn{5}{|l|}{ c) } \\
\hline $\begin{array}{c}\text { temperature } \\
\left(\mathrm{C}^{\circ}\right)\end{array}$ & $\begin{array}{c}\mathrm{i}_{\text {corr }} / \mu \mathrm{A} / \mathrm{cm}^{2} \\
\pm \text { S.D. }\end{array}$ & \multicolumn{2}{|c|}{-Ecorr/ mV } & $\bar{X}$ \\
\hline 25 & \multicolumn{2}{|l|}{$1823.0 \pm 2.12$} & 08 & 1821.5 \\
\hline 35 & \multicolumn{2}{|l|}{$5260.0 \pm 6.36$} & 02 & 5255.5 \\
\hline 45 & \multicolumn{2}{|l|}{$5268.0 \pm 5.66$} & 3 & 5264.0 \\
\hline 55 & \multicolumn{2}{|l|}{$10453.0 \pm 5.66$} & 4 & 10457.0 \\
\hline \multicolumn{5}{|l|}{ d) } \\
\hline $\begin{array}{c}\text { temperature } \\
\left(\mathrm{C}^{\circ}\right)\end{array}$ & $\begin{array}{c}\mathrm{i}_{\text {corr }} / \mu \mathrm{A} / \mathrm{cm}^{2} \\
\pm \mathrm{S} . \mathrm{D} .\end{array}$ & $-\mathrm{E}_{\text {corr }} / \mathrm{mV}$ & IE\% & $\bar{X}$ \\
\hline 25 & $308.0 \pm 6.36$ & 495 & 83 & 312.5 \\
\hline 35 & $1450.0 \pm 9.90$ & 494 & 72 & 1443.0 \\
\hline 45 & $2024.0 \pm 7.80$ & 487 & 62 & 2018.5 \\
\hline 55 & $4623.0 \pm 8.50$ & 493 & 56 & 4629.0 \\
\hline
\end{tabular}

rosion of mild steel in both solutions. The $\mathrm{E}_{\mathrm{a}}$ values were determined from the plots $\left(\ln \mathrm{j}_{\text {corr }}\right.$ versus $\left.1 / \mathrm{T}\right)$ and are given in Table 4. A decrease in inhibition yield with rise in temperature with analogous increase in corrosion activation energy in the presence of inhibitor compared to its absence is frequently interpreted as being suggestive of formation of an adsorption film of physical (electrostatic) nature.

\section{4. Adsorption Isotherm}

To obtain the surface coverage, $\theta$, it was assumed that the inhibition efficiency is because of the blocking effect of the adsorbed species and hence $\theta=\operatorname{IE~(\% )/100.~Here,~an~}$ attempt was made to test the Langmuir, Temkin, and Frumkin isotherms. The Langmuir adsorption isotherm is found a)

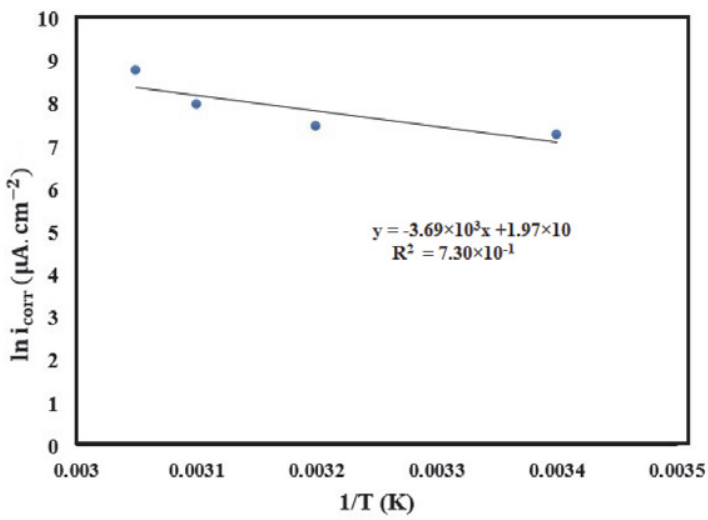

b)

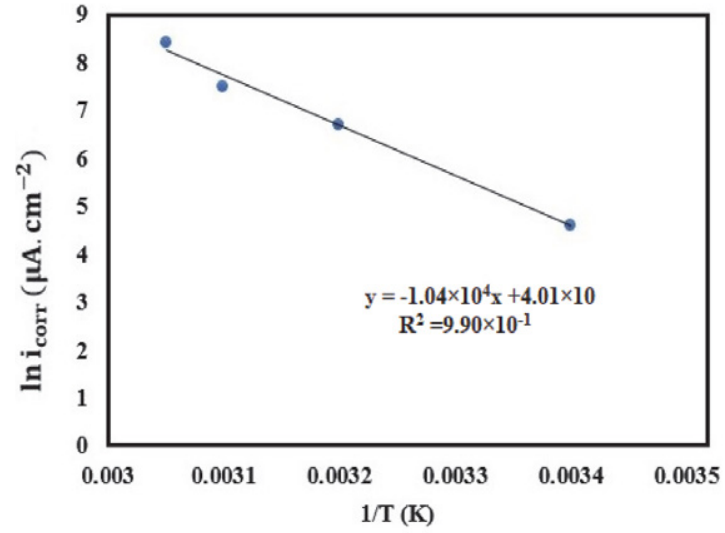

c)

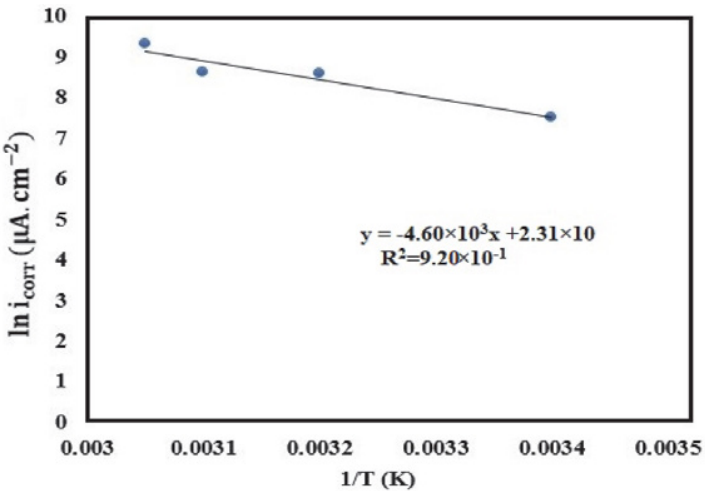

d)

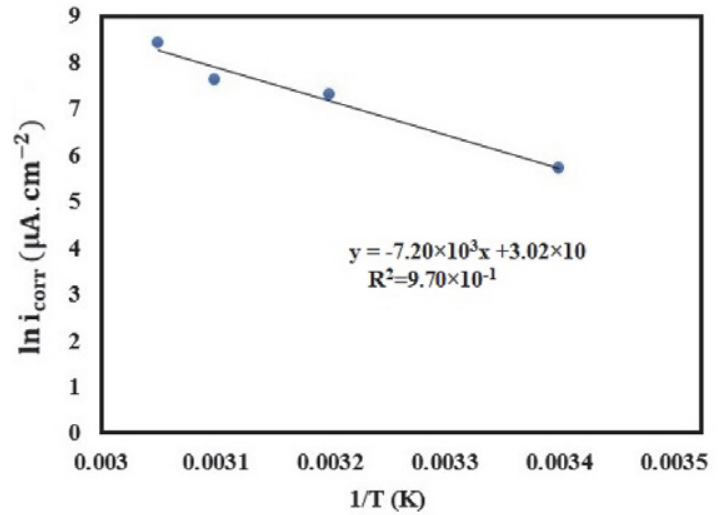

Figure 6. Arrhenius slopes calculated from corrosion current density for mild steel in $1 \mathrm{M}$ hydrochloric acid, a) without inhibitor, b) with inhibitor and $0.5 \mathrm{M}$ sulforic acid solution c) without inhibitor d) with inhibitor. 
a)

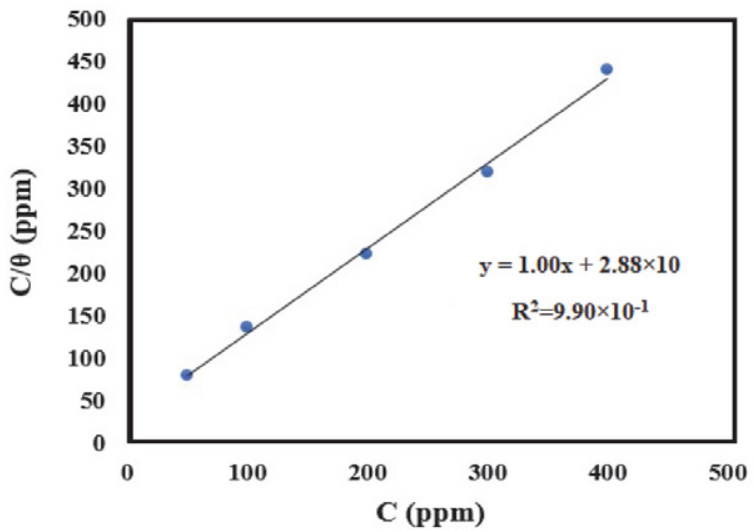

b)

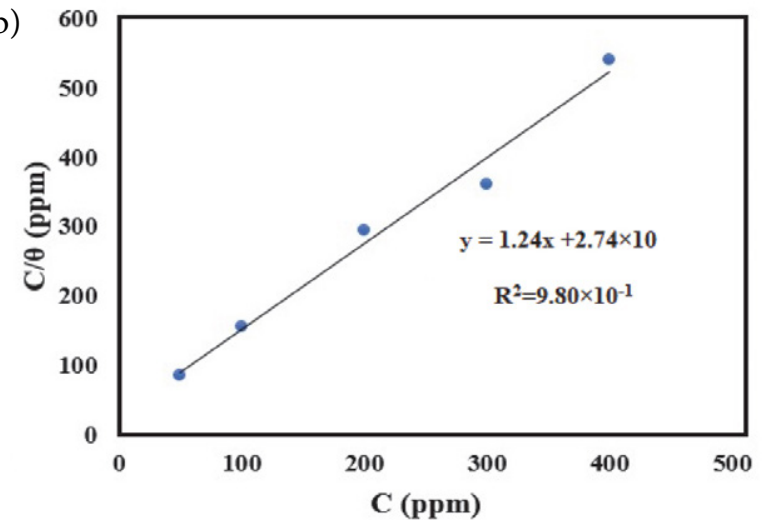

Figure 7. Langmuir adsorption isotherm on the mild steel surface in a) hydrochloric acid and b) sulfuric acid solution in the presence of inhibitor at $25 \pm 1{ }^{\circ} \mathrm{C}$.

to fit well with the experimental data (Fig. 7). This kind of isotherm is defined by the below equation: ${ }^{22}$

$$
\frac{C_{i n h}}{\theta}=\frac{1}{\mathrm{~K}_{\mathrm{ads}}}+\mathrm{C}_{i n h}
$$

where $\theta$ is the surface coverage, $\mathrm{C}_{\text {inh }}$ is the inhibitor concentration, and $\mathrm{K}_{\mathrm{ads}}$ is the adsorption equilibrium constant. The plot of $\mathrm{C} / \Theta$ versus $\mathrm{C}$ for solutions (Fig. 7) yields straight line with correlation coefficient close to 1.0 confirming the adsorption of the inhibitor on the sample fits the Langmuir isotherm. This isotherm is based on the assumptions that all the adsorption sites are equivalent and the ability of a molecule to be adsorbed at a given site is independent of the occupation of nearby sites. ${ }^{23}$

\section{5. Thermodynamic Parameters}

The adsorption equilibrium constant, $\mathrm{K}_{\mathrm{ad}}$, was calculated using equation (6). The Gibbs standard free energy of the adsorption of the inhibitor was explored by the following equation: ${ }^{24}$

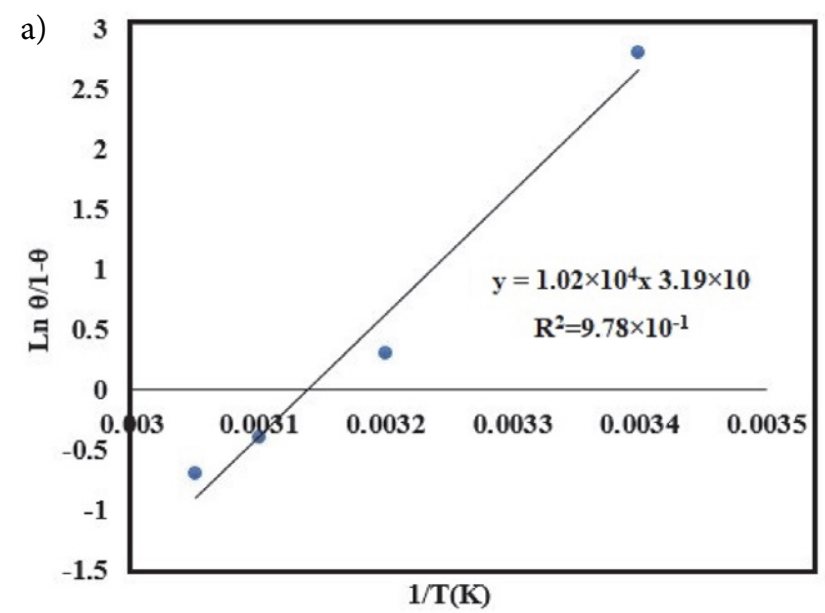

$$
\Delta \mathrm{G}_{\mathrm{ads}}^{\mathrm{o}}=-\mathrm{RT} \operatorname{Ln}\left(1 \times 10^{6} \mathrm{~K}_{\mathrm{ads}}\right)
$$

where $\mathrm{R}$ is the gas constant $(8.314 \mathrm{~J} / \mathrm{Kmol})$ and $\mathrm{T}$ is the absolute temperature $(\mathrm{K})$.

Also, the value of enthalpy of adsorption, $\Delta \mathrm{H}^{\circ}$ ads, was calculated from the below equation: ${ }^{25}$

$$
\frac{\theta}{1-\theta}=\operatorname{ACexp}\left(-\frac{\Delta \mathrm{H}_{\mathrm{ads}}^{\mathrm{o}}}{\mathrm{RT}}\right)
$$

where $\theta$ is surface coverage, $\mathrm{A}$ is an independent constant, $\mathrm{C}$ is concentration, $\mathrm{R}$ is gas constant, $\mathrm{T}$ is absolute temperature. Fig. 8 illustrates the plot of $\ln \left(\frac{\theta}{1-\theta}\right)$ versus $1 / \mathrm{T}$, and there the value of $\Delta \mathrm{H}^{\circ}$ ads was measured by the slope of the straight line. tion $(9):{ }^{26}$

Entropy of adsorption $\Delta \mathrm{S}^{\circ}$ ads is given by the equa-

$$
\Delta \mathrm{G}_{\mathrm{ads}}^{\mathrm{o}}=\Delta \mathrm{H}_{\mathrm{ads}}^{\mathrm{o}}-\mathrm{T} \Delta \mathrm{S}_{\mathrm{ads}}^{\mathrm{o}}
$$

The calculated values of $\mathrm{E}_{\mathrm{a}}, \Delta \mathrm{H}_{\mathrm{ads}}^{\circ}, \Delta \mathrm{G}_{\mathrm{ads}}^{\circ}$, and $\Delta \mathrm{S}_{\mathrm{ads}}^{\mathrm{o}}$ for mild steel in both solutions in absence and presence of

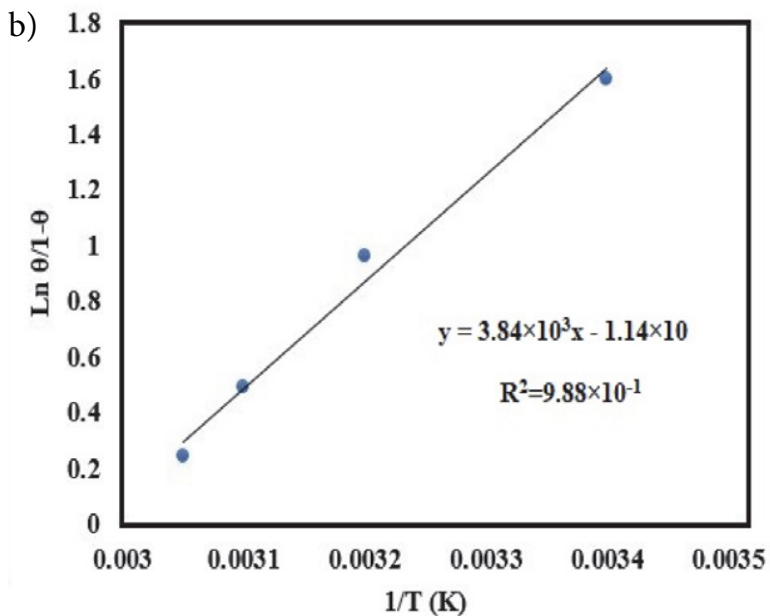

Figure 8. Plots of $\ln (\theta / 1-\theta)$ versus $1 / \mathrm{T}$ for mild steel in a) hydrochloric acid solution containing $300 \mathrm{ppm}$ of inhibitor and b) sulfuric acid solution containing $300 \mathrm{ppm}$ of inhibitor, at different temperatures. 
the optimum concentration of the inhibitor are reported in Table 4. Generally, the values of $\Delta \mathrm{G}_{\mathrm{ads}}^{\circ}$ around $-20 \mathrm{~kJ} / \mathrm{mol}$ or less negative are consistent with the electrostatic interaction between charged molecules and the charged metal surface (physisorption); those around $-40 \mathrm{~kJ} / \mathrm{mol}$ or more negative involve charge sharing or transfer from organic molecules to the metal surface to form a coordinate type of metal bond (chemisorption).

The derived values of $\Delta \mathrm{G}_{\mathrm{ads}}^{\mathrm{o}}$ for both solutions (>-40 and $<-20) \mathrm{kJ} / \mathrm{mol}$ is commonly interpreted with comprehensive adsorption (physical and chemical adsorption). ${ }^{27}$
For these solutions, the negative values of $\Delta \mathrm{G}_{\mathrm{ads}}^{\circ}$ showing the spontaneity of the adsorption process of inhibitor molecules on the steel surface. The negative signs of $\Delta \mathrm{H}_{\mathrm{ads}}^{\circ}$ reflect the exothermic nature of metoprolol behavior on the alloy. In this research, entropy of adsorption in both solutions is low and negative.

\section{6. SEM Observations}

Scanning electron micrographs (SEM) of the surface of mild steel immersed for $24 \mathrm{~h}$ in $1 \mathrm{M} \mathrm{HCl}$ and $0.5 \mathrm{M}$

Table 4. Thermodynamic and kinetic parameters for adsorption of inhibitor in sulfuric acid and hydrochloric acid solutions on the metal surface. (Results derived from two repeats of experiment.)

\begin{tabular}{ccccc}
\hline & $\mathbf{E}_{\mathbf{a}}(\mathbf{k J} / \mathbf{m o l})$ & $\boldsymbol{\Delta} \mathbf{H}_{\mathbf{a d s}}^{\mathbf{o}}(\mathbf{k J} / \mathbf{m o l})$ & $\Delta \mathbf{G}_{\mathbf{a d s}}^{\mathbf{o}}(\mathbf{k J} / \mathbf{m o l})$ & $\Delta \mathbf{S}_{\mathbf{a d s}}^{\mathbf{o}}(\mathbf{k J} / \mathbf{m o l ~ K})$ \\
\hline Hydrochloric acid & 30.9 & - & - & - \\
Sulfuric acid & 38.2 & - & - & - \\
Hydrochloric acid and inhibitor & 86.8 & -84.5 & -25.9 & -0.197 \\
Sulfuric acid and inhibitor & 59.9 & -31.9 & -26.0 & -0.020 \\
\hline
\end{tabular}

a)

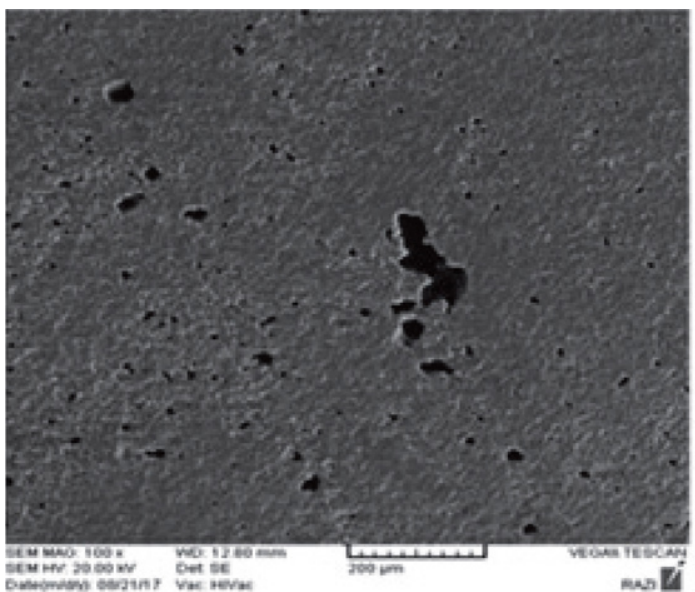

b)

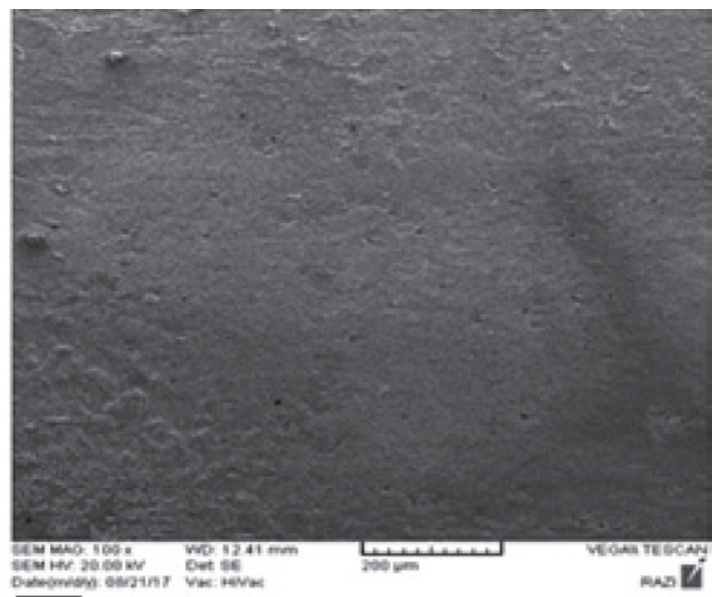

Figure 9. SEM images of mild steel in 1.0 M hydrochloric acid solution, a) blank, b) with inhibitor.

a)

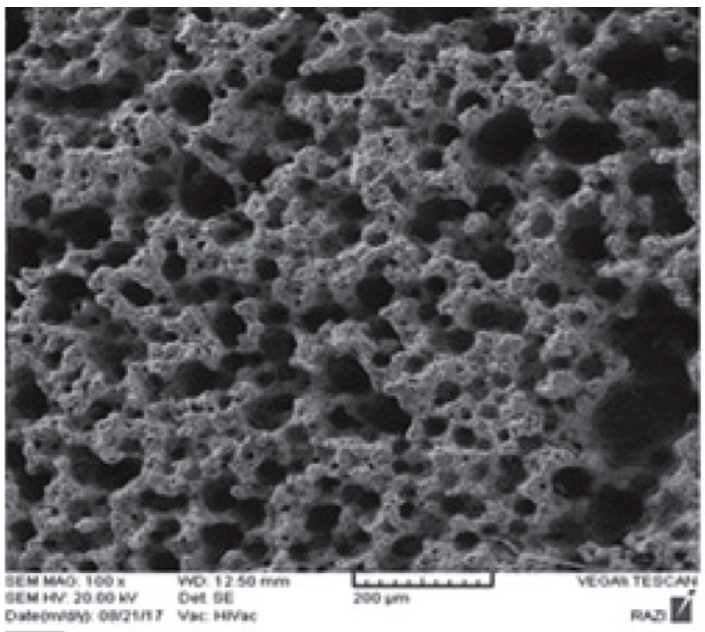

b)

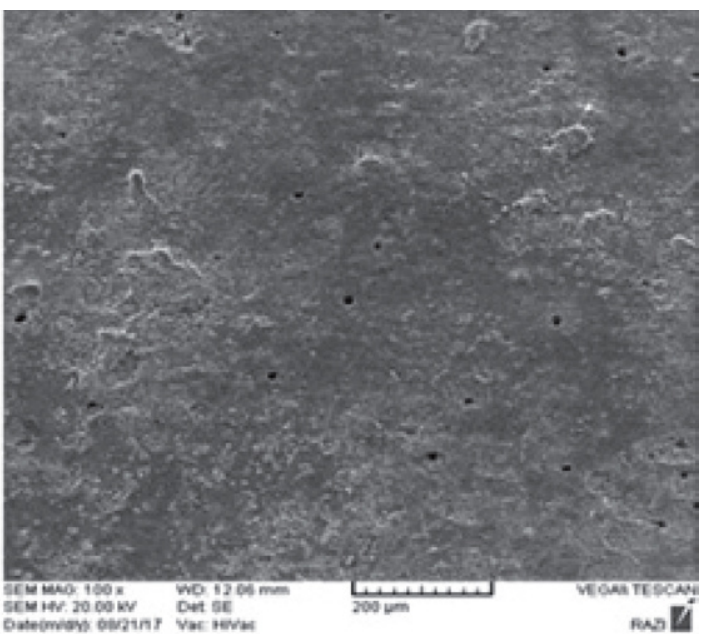

Figure 10. SEM images of mild steel in $0.5 \mathrm{M}$ sulfuric acid solution, a) blank, b) with inhibitor. 
$\mathrm{H}_{2} \mathrm{SO}_{4}$ solutions without and with the optimum concentration of inhibitor are shown in Fig. 9 and 10. The alloy surfaces in both blank solutions (Fig. 9a and 10a) were drastically damaged but in the presence of $300 \mathrm{ppm}$ metoprolol (Fig. 9b and 10b) were protected. This demonstrates the potential of metoprolol to act as an efficient corrosion inhibitor for the mild steel in the acid media.

\section{Conclusions}

The below conclusions were drawn for this study:

1. Metoprolol tablet was found to be a suitable inhibitor of mild steel corrosion in acid media, especially in $\mathrm{HCl}$.

2. Inhibition efficiency increased with an increase in metoprolol concentration up to $300 \mathrm{ppm}$ while it decreased with increase in temperature.

3. The inhibitor concentration ( $300 \mathrm{ppm})$ at $25 \pm 1{ }^{\circ} \mathrm{C}$ reached to a maximum inhibition efficiency.

4. The free energy of adsorption indicates that the process was spontaneous and the adsorption enthalpy indicated that the process is exothermic with negative entropy of adsorption.

5. The EIS measurements showed that with addition of the inhibitor up to $300 \mathrm{ppm}$, the charge transfer resistance enhances and the double layer capacitance $\left(\mathrm{C}_{\mathrm{dl}}\right)$ reduces.

6. Potentiodynamic polarization measurements showed that the tablet acts as a mixed-type inhibitor in both solutions.

7. The results obtained from potentiodynamic polarization and EIS are consistent.

8. The adsorption of the inhibitor on the alloy surface in the solutions obeys Langmuir isotherm.

9. The SEM investigations revealed formation of a uniform and protective film on the alloy.

\section{References}

1. B. E. A. Rani, B. B. J. Basu, Int. J. Corros. 2012, 2012, 1-15. DOI: $10.1155 / 2012 / 380217$

2. X. Li, S. Deng, H. Fu, G. Mu, Corros. Sci. 2009, 51, 620-634. metoprolola fizikalna, eksotermna in spontana

3. M. J. Bahrami, S. M. A. Hosseini, P. Pilvar, Corros. Sci. 2010, 52, 2793-2803. DOI:10.1016/j.corsci.2010.04.024

4. R. M. Palou, O. Olivares-Xomelt, N. V. Likhanova, InTech. 2014, 432-465.
5. S. M. A. Hosseini, M. Salari, M. Ghasemi, Mater. Corros. 2009, 60, 963-968. DOI:10.1002/maco.200905214

6. S. Bilgic, M. Sahin, Mater. Chem. Phys. 2001, 70, 290-295. DOI:10.1016/S0254-0584(00)00534-4

7. H. D. Lece, K. C. Emregul, O. Atakol, Corros. Sci. 2008, 50,1460-1468. DOI:10.1016/j.corsci.2008.01.014

8. G. Mu, X. Li, Q. Qu, J. Zhou, Corros. Sci. 2006, 48, 445-459. DOI:10.1016/j.corsci.2005.01.013

9. E. Samiento-Bustos, J. G. Gonzalez Rodriguez, J. Uruchurtu, G. Dominguez- Patino, V.M. Salinas-Bravo, Corros. Sci. 2008, 50, 2296-2303. DOI:10.1016/j.corsci.2008.05.014

10. A. C. Bastos, M. G. Ferreira, A. M. Simoes, Corros. Sci. 2006, 48, 1500-1512. DOI:10.1016/j.corsci.2005.05.021

11. M. Sahin, G. Gece, F. Karc1, S. Bilgic, J. Appl. Electrochem. 2008, 38, 809-815. DOI:10.1007/s10800-008-9517-3

12. G. Gece, Corros. Sci. 2008, 50, 2981-2992. DOI:10.1016/j.corsci.2008.08.043

13. R. T. Loto, C.A. Loto, A. P. I. Popoola, J. Mater. Environ. Sci. 2012, 3, 885-894.

14. D. G. Ladha, U. J. Naik, N. K. Shah, J. Mater. Environ. Sci. 2013, 4, 701-708.

15. N. O. Eddy, S. A. Odoemelam, J. Mater. Sci. 2008, 4, 87-96.

16. A. S. Mahdi, Int. J. Adv. Res. Eng. Tech. 2014, 5, 99-107.

17. N. S. Patel, S. Jauhari, G. N. Mehta, Acta Chim.Slov. 2010, 57, 297-304.

18. M. Outirite, M. Lagrenée, M. Lebrini, M. Traisnel, C. Jama, H. Vezin, F. Bentiss, Electrochim. Acta. 2010, 55, 1670-1681. DOI:10.1016/j.electacta.2009.10.048

19. M. S. Al-Otaibi, A. M. Al-Mayouf, M. Khan, A. A. Mousa, S. A. Al-Mazroa, H. Z. Alkhathlan, Arabian J. Chem. 2014, 7, 340-346. DOI:10.1016/j.arabjc.2012.01.015

20. A. Samide, I. Bibicu, M. Rogalski, M. Preda, Acta Chim.Slov. 2004, 51, 127-136.

21. B. El Mehdi, B. Mernari, M. Traisnel, F. Bentiss, M. Lagrenee, Mater. Chem. Phys. 2003, 77, 489-496.

DOI:10.1016/S0254-0584(02)00085-8

22. L. Herrag, B. Hammouti, A. Aouniti, S. El Kadiri, R. Touzani, Acta Chim. Slov. 2007, 54, 419-423.

23. P. Atkins, J. de. Paula, Oxford University Press, Oxford, USA, Physical Chemistry, Eighth, 2006.

24. A. Pal, S. Dey, D. Sukul, Res. Chem. Intermed. 2016, 42, 45314549. DOI:10.1007/s11164-015-2295-8

25. Gh. Golestani, M. Shahidi, D. Ghazanfari, Appl. Surf. Sci. 2014, 308, 347-362. DOI:10.1016/j.apsusc.2014.04.172

26. H. Ashassi-Sorkhabi, B. Shaabani, D. Seifzadeh, Appl. Surf. Sci. 2005, 239, 154-164.

DOI:10.1016/j.apsusc.2004.05.143

27. E. A. Noor, A. H. Al-Moubaraki, Mater. Chem. Phys. 2008, 110, 145-154. DOI:10.1016/j.matchemphys.2008.01.028 


\section{Povzetek}

Proučevali smo inhibicijo korozije jeklene zlitine (st37) s tabletami metoprolola v $1 \mathrm{M}$ klorovodikovi kislini in v 0,5 M žveplovi kislini. Uporabili smo tri metode: potenciodinamično polarizacijo, elektrokemijsko impedančno spektroskopijo in vrstično elektronsko mikroskopijo, SEM. Pridobljeni parametri so pokazali, da različne količine metoprolola inhibirajo korozijo jekla v raztopinah kislin $\mathrm{HCl}$ in $\mathrm{H}_{2} \mathrm{SO}_{4}$. Korozijska odpornost zlitine se je povečevala glede na višanje koncentracije metoprolola do 300 ppm, a se je zmanjšala pri višji temperaturi. Parametri, pridobljeni iz polarizacijskih krivulj, so pokazali, da je učinkovina inhibitor mešanega tipa. Rezultati, pridobljeni z različnimi metodami, so se med seboj ujemali. Ugotovili smo, da je adsorpcija ter da se ujema z Langmuirjevim adsorpcijskim modelom. SEM mikrografije se skladajo $\mathrm{z}$ adsorpcijskim obnašanjem tablete 